\title{
Research on the College English Linguistics Teaching Based on the Cultivation of Applied Talents
}

\author{
Wen Jiang \\ Haikou College of Economics, Haikou, Hainan, China, 110372
}

Keywords: Applied Talents Training; College English; Linguistics Teaching

\begin{abstract}
With the increasingly close communication between the international, and the application of personnel training is the main direction of the current college personnel training, based on the application of personnel training mode of college English teaching reform is very urgent and linguistic is college English teaching and it is of great practical significance to improve the students' practical ability and oral level, and to reform the teaching of college English linguistics. Therefore, this paper analyzes the teaching of college English linguistics based on the application of talents, and provides the guarantee for the development and development of college English linguistics.
\end{abstract}

\section{Introduction}

Under the influence of economic globalization, Chinese comprehensive national strength is increasing, international exchanges are more closely, and the demand for professional application talents is increasing in the process of international exchange. In order to adapt to the trend of social reform and development, type of personnel training is the needs of social development at this stage. English as an international language, the application of personnel training mode requires the need to have a certain degree of English language skills [1]. The main goal of college English teaching is to cultivate students' English application ability, improve students' English level and meet the needs of students' individual development. The current international environment makes college English linguistics teaching a certain challenge and opportunity. Therefore, it is imperative to reform college English linguistics under the cultivation of applied talents.

\section{The Application of College English Linguistics Teaching}

Linguistics is a kind of language learning method, has certain guiding and scientific characteristics, can help students master the learning method, so that teachers can use the language rationally. In international communication, English as a common language, and college English linguistics teaching is mainly used in the following aspects:

Grammar Application. For most students, it is difficult to master and proficient the grammar knowledge in the process of English learning. Linguistics can simplify the complex knowledge and make the learning method more flexible. The traditional teaching mode is only about the students' hard learning, learning efficiency is low, and linguistics teaching can effectively deepen the students' deep understanding of the knowledge points, to stimulate students to learn enthusiasm and enthusiasm for learning for students to create a harmonious, cheerful learning atmosphere, in a relaxed environment for grammar knowledge a certain understanding and master.

Vocabulary Application. Vocabulary as an important basis for English language learning, in the traditional teaching model requires students to a large number of English vocabulary for rote, and require students to master the vocabulary larger, so that students have a greater psychological burden and learning pressure, learning efficiency low [2]. If the vocabulary knowledge cannot be fully grasped, it is difficult to other deep knowledge to start learning, so in college English teaching vocabulary is the focus of its teaching. In the college English vocabulary teaching application of linguistics, so that students go to the context, according to the meaning of the sentence itself and the context of the vocabulary to understand and master the language learning in linguistics as its 
theoretical guidance, not only for students to the meaning of the word generate understanding and understanding, the similar terms and the meaning of vocabulary to produce a certain understanding, so as to improve learning efficiency and learning quality.

Language Sense Application. The sense of language in English learning is to examine students' cognitive ability and understanding ability in English language. It is also a necessary condition for learning English. The cultivation of English language sense requires the guidance of linguistics. Students are required to deal with the relevant social culture first understanding, on this basis to start the English teaching work, and in the teaching of English cultural background infiltration and integration, students in the process of learning English foreign cultural background, cultural connotation and the context of the time to think, so as to deepen the understanding of language, to achieve the cultivation of students sense of language.

\section{The Status Quo of College English Linguistics Teaching Based on the Application of Personnel Training}

As the theoretical level of college English linguistics teaching is deep, the content is wide, the time is small and the concept is more and it is difficult to meet the demand of talent cultivation in the traditional teaching mode. From the current situation of college English linguistics teaching, there are still many problems to be solved[3]. In the field of related educational research, there is little research on this aspect. On the one hand, mainly because the teachers pay the time, more energy, but its teaching effect is not ideal, resulting in teachers have a negative psychological, and the other is mainly due to the lack of students clear learning objectives, In the learning process to spend a lot of time in the word and academic definition of rote, leading to the study of English linguistics goals cannot be achieved. The problems in the teaching of college English linguistics are mainly reflected in the following aspects:

First, it lacks of clear teaching objectives. In the course of college English teaching, it mainly regards English as a basic language, mainly in order to cultivate the ability of students' language foundation, and mainly in the teaching process, which is defined as basic English teaching. Under the influence of the traditional examination-oriented education, some teachers in order to achieve a certain teaching results for students to explain the relevant pro forma strategy, resulting in students of English linguistics theoretical knowledge of the lack of a strong interest in the establishment of students learning English also have a certain impact The Second, the school lacks enough teachers to build [4]. With the reform of English teaching in colleges and universities in recent years, the teaching ability of teachers in colleges and universities has also been improved. However, there is a lack of practical training, training and learning in the construction of high-level faculty. So that the teaching team's ability to apply metaphorical language is difficult to be implemented, and the combination of theoretical knowledge and practical knowledge cannot be combined, which makes the development of college English linguistics teaching. Again, the teaching process lacks practical links. Based on the characteristics of college English linguistics, linguistics has strong academic characteristics, including the content of information system is huge, so in the process of theoretical teaching need to be associated with the actual, but in the actual teaching, because college English Linguistics teaching time is less, teachers focus on the teaching of key theoretical knowledge to explain and induction, while ignoring the reality of life links and examples of analysis, so that students cannot improve the analysis of language phenomena [5]. Teachers in the teaching process need to have a certain degree of professional knowledge and theoretical knowledge, which is a teacher should have the basic requirements, but some English teachers, although with a certain degree of language theory teaching ability and English language teaching ability, but In the actual teaching process often focus on theoretical teaching, and lack of attention to the cultivation of students' cognitive ability, in addition to the pursuit of deep-level theoretical knowledge of teachers, students of psychological knowledge, education and other aspects of the lack of research, there is a phenomenon of neglect, is not conducive to students in the learning process to give full play to their own subjective initiative, resulting in students of language application ability to cultivate and enhance the existence of restrictions. 


\section{College English Linguistics Teaching Reform Strategy Based on the Application of Personnel Training}

Change the Traditional Teaching Concept. In the current college English teaching, there are a number of colleges and universities using the traditional teaching model, the new curriculum teaching reform has not been understood and implemented in the classroom teaching teachers still occupy the dominant position, student status has not been attention and change, students It is still a passive acceptance of the knowledge imparted by teachers, resulting in the participation of students in teaching is not high, learning the lack of enthusiasm, this situation on the cultivation of students self-learning ability constraints, not only the lack of attention to students language communication, but also not conducive to the improvement of students' English reading and writing ability is not only difficult to achieve the corresponding teaching objectives, but also does not meet the application of personnel training mode of teaching the original intention and teaching objectives [6]. Therefore, in the application of personnel training mode, college English linguistics teaching teachers need to change their traditional teaching concept, breaking the traditional teaching philosophy of the shackles of their own teaching ideas and teaching ideas to innovate. And the application of the teaching concept requires teachers to go to the reality of life, the community, enterprises in the talent needs and requirements to have a certain understanding, and the current social situation and personnel training model have a certain understanding, to strengthen the students' language application ability of the training. On the one hand, schools should also strengthen the training of faculty and staff work, through the training to improve the teaching level of teachers, the use of application-oriented teaching philosophy, increase the training of applied talents.

Use New Teaching Methods to Stimulate Students' Learning Interest. To improve the quality of students' learning and change their learning habits, we must establish clear learning objectives and learning methods. Under the training mode of applied talents, the new teaching methods should be applied in the process of college English linguistics, which can stimulate students' interest in learning and abandon the traditional teaching methods so that students can experience the new teaching methods in real life Intuitive feel, so that students learn to improve habits. In addition, due to the individualization and differentiation of students, in the teaching of students need to develop different teaching programs, combined with the characteristics of students and the level of knowledge in accordance with their aptitude, to design targeted training model, to develop a diversified teaching measures [7]. Such as in English teaching through the way to carry out the debate to start teaching activities, to create a strong teaching range, so that each student is integrated into the teaching, and take the initiative to collect relevant English information to consolidate their own knowledge of English, face and knowledge range, in English linguistics learning to enhance students' own English application skills level.

Strengthen the Combination of Theoretical Knowledge and Practice. In the application of personnel training mode, the ultimate goal is to allow students to combine the theory and practice effectively, so in college English linguistics teaching to strengthen the combination of theoretical knowledge and practice, teachers should do a good job with the students communication and exchange work, and organize extracurricular teaching activities, design teaching activities related to classroom content, so that English language learning is not only written in writing, but in the real life has been widely used to create a professional application of talent, so that students In the course of practice to continuously improve the English application ability and ability to express. For example, teachers can organize students to run English learning weekly in English, and publish in the school, through the evaluation of the model to select the best English newspapers, stimulate students' interest and initiative, or organize students to translate English essays or masterpieces , And published in the form of translation activities [8]. This method not only helps to cultivate the students' language application ability, so that the application-oriented talent training mode can be implemented so that students can better apply the knowledge they have learned in real life, so that students can make their own deficiencies to produce a correct understanding, in order to better students of the application of skills training. 
Strengthen the Reform of Teaching Evaluation Model. The traditional English examination system is usually the combination of the final results and the usual results, the comprehensive assessment of the level of students' English learning, this assessment model is based on the idea of examination-oriented education, students often learn in the knowledge of rote, lack of correct understanding of the characteristics, but also not conducive to the cultivation of applied talents. Therefore, it is also necessary to reform the teaching evaluation mode in the teaching of college English linguistics. The important way of reforming the teaching evaluation mode is to concentrate the knowledge accumulation and knowledge exchange in the usual learning as the key content of the examination, and to improve the students' understanding of the importance of English communication and language application to a certain extent, effect [9]. Teachers should go deep into the student life to understand the students' English language application, and incorporate it into daily performance and curriculum evaluation, so that students attach importance to the daily life of English applications, but also help students to daily teaching material accumulation and consolidation, for English learning to lay a solid foundation to improve their own English application skills and communication skills.

\section{Conclusion}

College English teaching and social development are closely linked, with the social development of the demand for applied talents increased in the college English language teaching requires teachers to attach importance to the cultivation of applied talents in the teaching process to continue to teaching methods, teaching ideas and teaching methods to innovate and improve, improve students' English application skills, so as to better meet the social development and national development of the demand for applied talents.

\section{References}

[1] Li Pei. Application of applied talents under the target of college English teaching strategies[J]. Journal of Southwest Agricultural University (Social Science Edition), 2012, 05: 209-210

[2] Qin Jing. Study on College English Classroom Teaching Mode Based on Applied Talents [J] Journal of China Three Gorges University (Humanities and Social Sciences), 2012, S2: 180-181.

[3] Hou Lixiang, Zhang Chunyan. Study on College English Learning Model under the Objective Training of Applied Talents [J]. Journal of Changchun Institute of Technology (Social Science Edition), 2015, 04: 142-145

[4] Zhang Liying.Application of Talent Cultivation Mode in College English Teaching Quality Assurance System [J] .Development, 2016, 10: $58+60$.

[5] Wang Dandan.Study on the Cultivation of College English I-CAN Based on the Cultivation of Practical Talents[J]. Journal of Wuhan Metallurgical Management College, 2016, 03: 73-75.

[6] Tang Yujuan. College English teaching and international trade professional application of talent training path [J]. Foreign trade, 2017, 03: 146-148.

[7] He Ping. On the Reform of College English Teaching in Independent Colleges - A Preliminary Study on the Mode of Cultivating College English Applied Talents [J]. SCIENCE \& TECHNOLOGY (WESTERN), 2010, 09: 112-113.

[8] Zhang Jingping, Zhao Haiyan. Application of talent training model under the college English teaching research[J]. Chinese talent, 2013, 06: 248-249.

[9] Xu Jun. Undergraduate college under the application of personnel training mode of college English teaching reform[J]. English square, 2015, 10: 64-66. 